\title{
نامه به سردبير
}

\section{همه كيرى جهانى ويروس كرونا و تاثير تحريم هاى سياسى و اقتصادى عليه ايران}

\author{
نشريه بايش

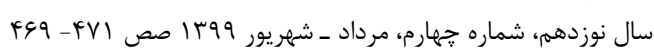

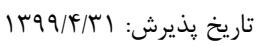

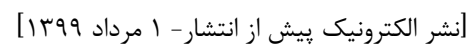

سردبير محترم

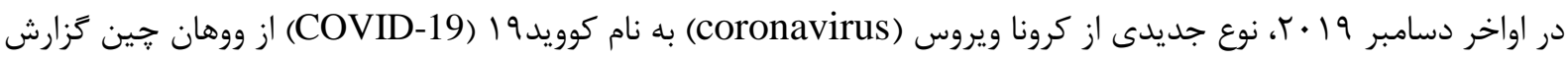

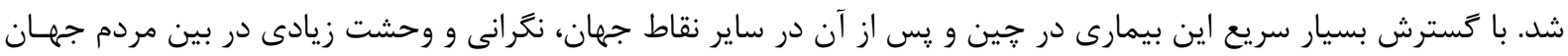

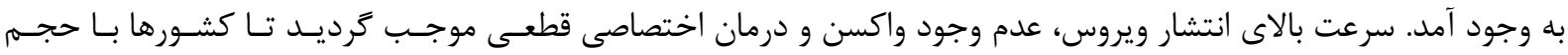

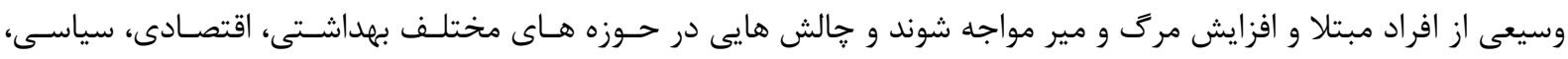

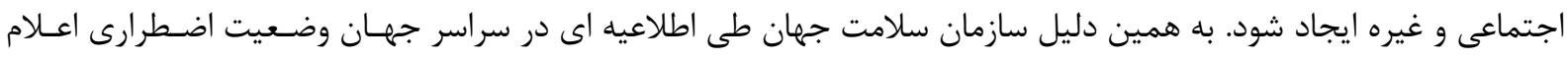
كرد

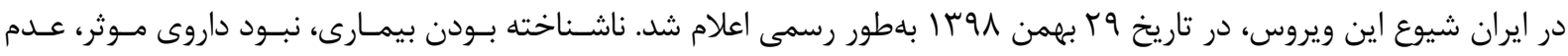

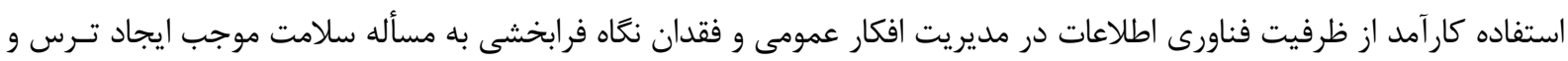

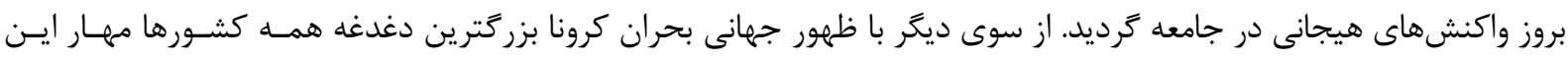

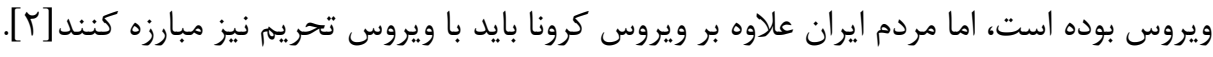


در يى تحريمهاى اقتصادى، ابعاد مختلف حقوق مندرج در ميثاق بينالمللى حقوق اقتصادى، اجتماعى و فرهنخـى از جملـه حـق حيـات مـورد

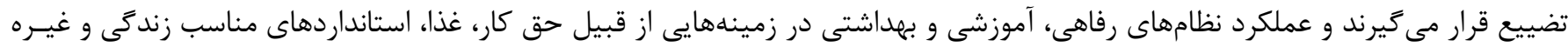

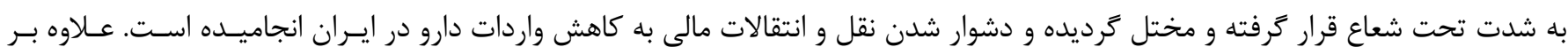

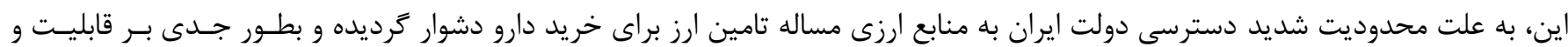

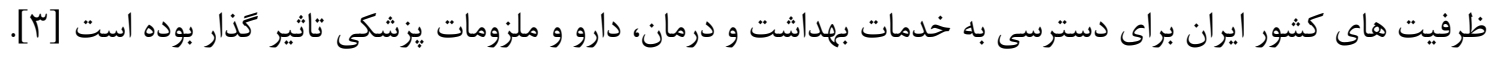

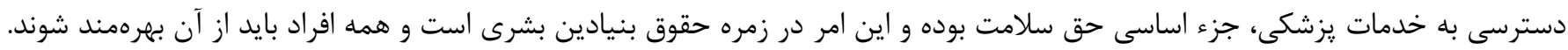

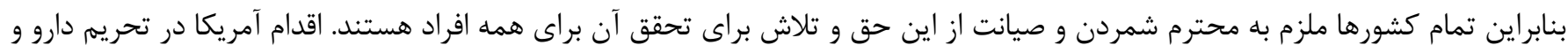

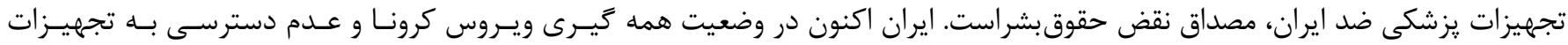

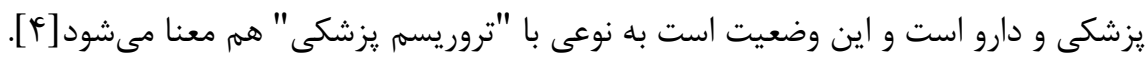

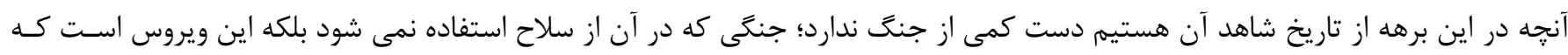

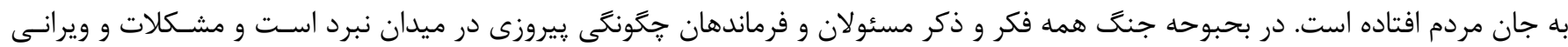

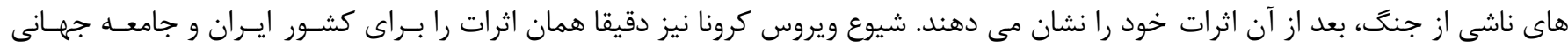

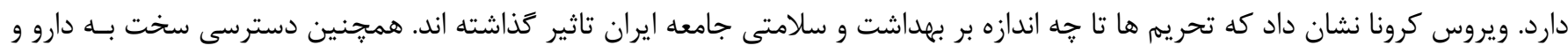

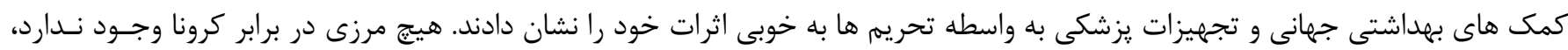
تنها مرزى كه مى تواند از مردم ايران در برابر اين ويروس محافظت كند ماند مرزهاى اخلاق است. اينكه حقوق همه انسان ها محترم شمرده شـود و

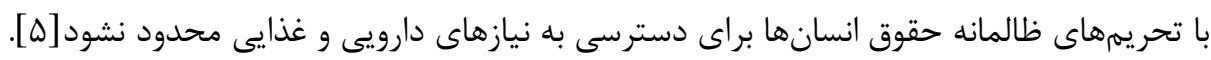

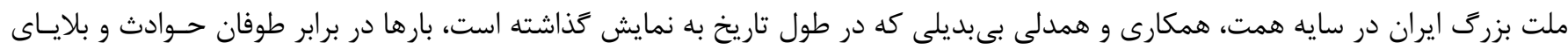

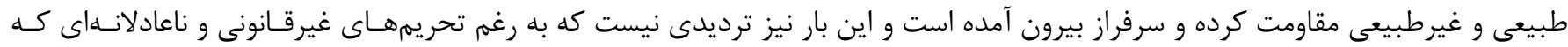

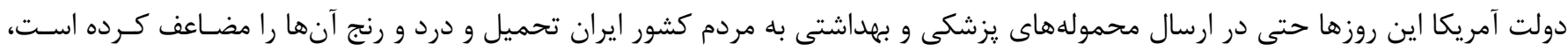

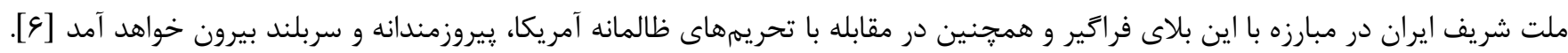

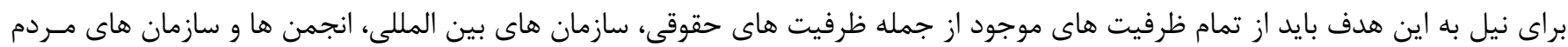

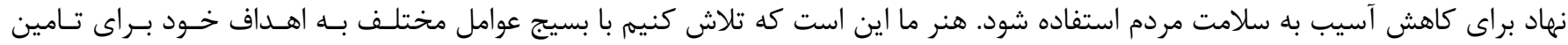

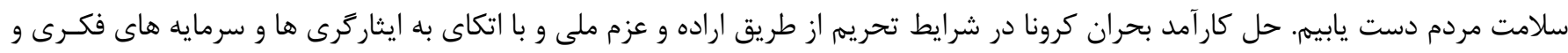

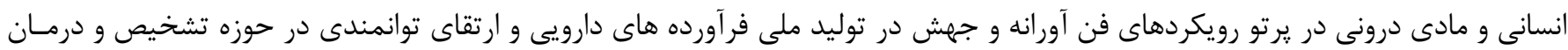

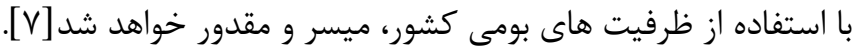

با تقديم احترام

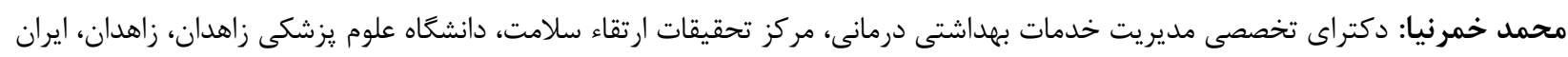

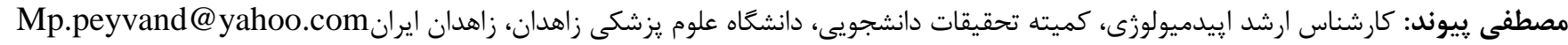

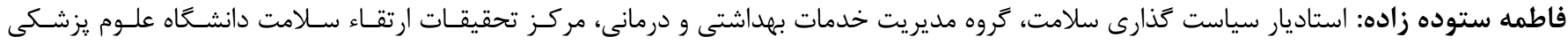
زاهدان، زاهدان، ايران 


\section{منابع}

1. Tang PF, Hou ZY, Wu XB, et al. Expert consensus on management principles of orthopedic emergency in the epidemic of coronavirus disease 2019. Chinese Medical Journal 2020;133:10961098doi:10.1097/CM9.0000000000000810

2. Doshmangir L, Mahbub Ahari A, Qolipour K, Azami-Aghdash S, Kalankesh L, Doshmangir P, et al. East Asia's Strategies for Effective Response to COVID-19: Lessons Learned for Iran. Management Strategies in Health System 2020; 4:370-373 [in Persian]

3. Zamani S G, Gharib Abadi K. Sanctions as State's Violation of International Obligations in Protection of Human Rights. Medical Law Journal 2017; 11:111-135 [in Persian]

4. Gorji A. Sanctions against Iran: The Impact on Health Services. Iranian Journal of Public Health 2014;43:381-382

5. Gharebaghi R, Heidary F. COVID-19 and Iran: swimming with hands tied! Swiss Medical Weekly Journal 2020;

7: $1-2$

6. Peyravi M, Marzaleh MA. The Effect of the US Sanctions on Humanitarian Aids during the Great Flood of Iran in 2019. Prehospital and Disaster Medicine 2020;35:233-234

7. Kokabisaghi F, Miller AC, Bashar FR, Salesi M, Zarchi AA, Keramatfar A, Pourhoseingholi MA, Amini H, Vahedian-Azimi A. Impact of United States political sanctions on international collaborations and research in Iran. BMJ Global Health 2019; 4: 1-7 